\title{
FIVE NEW SPECIES OF GUATTERIA (ANNONACEAE) FROM FRENCH GUIANA, GUYANA AND SURINAME
}

\author{
UWE SCHARF $^{1}$, PAUL J.M. MAAS ${ }^{2} \&$ WILFRIED MORAWETZ ${ }^{1}$
}

\begin{abstract}
SUMMARY
As a precursor to a taxonomic treatment of Annonaceae for the Flora of the Guianas project, five new species of Guatteria Ruiz \& Pav. from French Guiana, Guyana and Suriname (Northern South America) are described here.
\end{abstract}

Key words: Annonaceae, Guatteria, tropical South America, French Guiana, Guyana, Suriname, taxonomy.

\section{INTRODUCTION}

Amongst the Neotropical genera of Annonaceae, Guatteria Ruiz \& Pav. is one of the largest. Chatrou et al. (2004) reports 265 species, though the actual number may exceed this. The genus is easily recognised by the combination of axillary flowers/inflorescences with clearly visible articulation on the pedicel, an apocarpous fruit of stipitate monocarps and an impressed primary vein on the upper side of the leaf. The taxonomy of the genus is still based on the treatments of Fries (1939, 1941, 1943, 1948a, b, c, 1949, 1950a, b, 1952, 1953, 1957a, b, 1960), whose work was based on the relatively few collections available at that time, a situation which in recent years has greatly improved. While accounts covering parts of the genus have appeared in several regional floras and checklists (e.g. Steyermark et al., 1995; Boggan et al., 1997; Hollowell et al., 2001), a new revision of this diverse and taxonomically challenging genus as a whole has yet to be made. First steps towards this goal can best be directed towards amply collected areas, providing a good reflection of the diversity present. The Flora of the Guianas project, coordinated by the Utrecht branch of the National Herbarium of the Netherlands, offered such an opportunity. The large number of specimens of Guatteria collected in the Guianas in the last 250 years and deposited at the Herbarium of the Utrecht branch of the National Herbarium of the Netherlands (U) and in parts on loan at the Herbarium of the Leipzig University (LZ) were the generous base for improved understanding of formerly insufficiently known taxa. Many recent collections of high quality, particularly from more remote places and/or from higher elevations, have until now been difficult or impossible to identify to known species, e.g. using Fries' keys (1939). Such collections could not even be unambiguously assigned to any particular

1) Universität Leipzig, Institut für Botanik, Johannisallee 21, D-04103 Leipzig, Germany; e-mail: uscharf@uni-leipzig.de and morawetz@uni-leipzig.de

2) Nationaal Herbarium Nederland, Utrecht University branch, Heidelberglaan 2, 3584 CS Utrecht, The Netherlands; e-mail: p.j.m.maas@bio.uu.nl 
of Fries' sections within Guatteria, which according to recent work appear to include many non-monophyletic groupings (R.H.J. Erkens, pers. com.). Scharf et al. (2005) described five new species from the Pakaraima Mountains in Guyana. In advance of a revision of Guatteria (Annonaceae) for the three Guianas five more new species from the Guianas are described here. Diagnostic characters of the new species are listed below the respective descriptions. Measurements of the pedicel relate to the whole length of the flower stalk, including both the part below the articulation ('peduncle') and the part above the articulation ('pedicel s.str.') ${ }^{1}$. Coordinates, if not mentioned on the label, were inferred from printed books (Hoff \& Cremers, 1996, The Lands and Surveys Department, 2001), maps (see list of references) as well as from sources on the internet (Geonames, Falling Rain).

\section{Guatteria anthracina Scharf \& Maas, spec. nov. - Fig. 1; Map 1}

Species foliis anthracinis, angustis, costa supra pilis longis ornatis distincta. - Typus: Lindeman, Stoffers et al. 429 (holo U; iso BBS, C, F, NY, S), Suriname, Lely Mts, 550-710 m, N $4^{\circ} 25^{\prime}$, W $54^{\circ} 39^{\prime}, 26$ Nov. 1975.

= Guatteria aff. oblonga sensu Maas \& Maas-van de Kamer (2002: 62); not R.E. Fr.

= Guatteria sp. 2, in Ribeiro et al. (1999: 133).

Tree or treelet, 7-30 m tall, 8-35 cm diam.; young twigs densely covered with appressed, short, light brown to whitish hairs, soon glabrous. Leaves: petiole 4-7 by 1-2 mm; lamina narrowly elliptic to ovate, $7-14(-16)$ by $2-4 \mathrm{~cm}$, chartaceous, base acute, apex acuminate (acumen 5-25 mm long) to acute, satiny shiny to dull, very dark brown to blackish green above, dark brown below, sparsely covered with appressed hairs above to glabrous, but primary vein covered with a dense row of erect to incurved, golden hairs, particularly when young, sparsely to densely covered with appressed, short to long (along primary vein) hairs below, secondary veins indistinct, slightly raised above, $7-13$ on either side of primary vein (intersecondaries hard to distinguish from the secondaries), angle of secondary veins with primary vein $65-75^{\circ}$, loop-forming at right to acute angles $\left(60-90^{\circ}\right)$, smallest distance between loops and margin 2-4 $\mathrm{mm}$. Flowers solitary, successively 2-4 times flowering from the same axil; pedicels 12-18 mm long, densely covered with appressed hairs; sepals broadly triangular, 4-6 by $3-5 \mathrm{~mm}$, laterally reflexed, both sides rather densely covered with appressed, light coloured hairs, inner base glabrous; petals obovate, 12-16(-18) by (5-)9-13 mm, green, yellowish, or cream in vivo, both sides in open flower bud rather densely covered with appressed, long hairs, in maturing flowers hairs very short; stamens 90-120, c. $1 \mathrm{~mm}$ long, flat to slightly umbonate (Lindeman, Stoffers et al. 429), orange in vivo and sicco, connective shield densely papillate; carpels 40-50, blackish with whitish hairs in between. Monocarps 20-30, ellipsoid, 9-11 by $4-5 \mathrm{~mm}$, apiculate (apiculum $<1 \mathrm{~mm}$ long), green in vivo, black to dark reddish brown in sicco, densely covered

1) Inflorescence: According to Chatrou (1998), the inflorescences of all Annonaceae can be considered as terminal. Apparently axillary inflorescences in genera such as Guatteria, Klarobelia, and Pseudomalmea consist of a short shoot, developing primarily from a leaf-axillary position, subtending a terminal pedicel with flower. The distinction between these two structures is in most cases clear, demarcated by an articulation. The short shoot bears a variable number of bracts which occasionally are larger and leaf-like in appearance. 


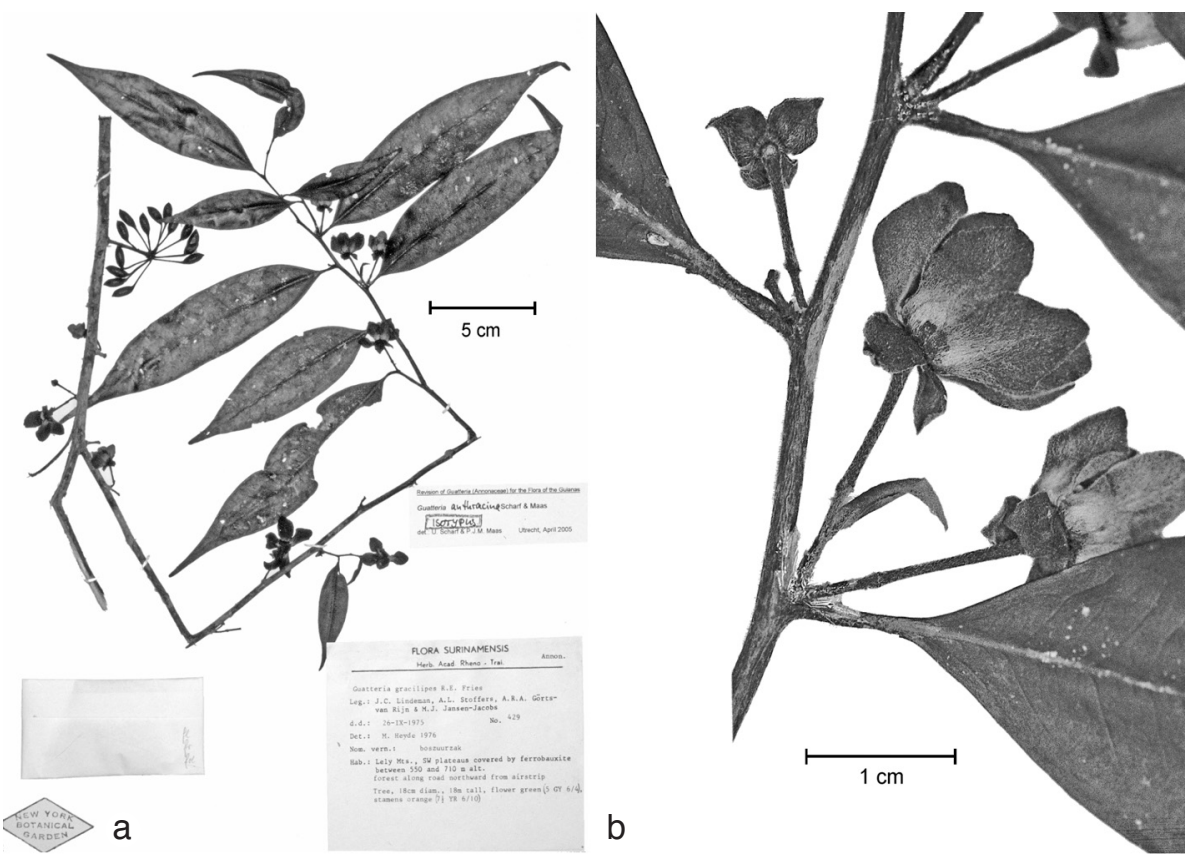

Fig. 1. Guatteria anthracina Scharf \& Maas. a. Twig with flowers, fruits and leaves; c. flowers (Lindeman, Stoffers et al. $429(\mathrm{NY})$ ).

with appressed, whitish hairs when young, some hairs persisting at base and apex, stipes 13-16(-25) mm long, slender, maturing red. Seeds ellipsoid to ovoid, 8-10 by $4 \mathrm{~mm}$, apex obtuse, shiny, conspicuously grooved, maroon.

Distribution - French Guiana, Suriname, Guyana, Brazil (Amapá, Amazonas).

Habitat \& Ecology - In primary or secondary forest, along rivers, on hill slopes, moist, non-inundated, on brown sand, sandy, or clayish soil. Elevation 20-915 m.

Phenology - Flowering: June to January; fruiting: July to December.

Etymology - This species has been named anthracina ('coal-black') after the very dark appearance of the dried leaves.

Notes - 1. The leaf shape of G. anthracina is somewhat similar to that of G. schomburgkiana Mart., but the pedicels are longer in G. anthracina (12-18 vs 5-10 mm), the monocarps more numerous and pointed (20-30 vs 5-18 and round), and the stipes are much longer (13-16 vs $0-3 \mathrm{~mm})$.

2. Guatteria procera R.E. Fr. is another species with dark drying leaves, but that species has a dense indument of erect, long, brownish hairs on all parts, except for the upper side of the lamina.

3. Guatteria liesneri D.M. Johnson \& N.A. Murray from Amazonian Venezuela and Brazil (Upper Rio Negro region, see Johnson \& Murray, 1990), is another species with dark drying leaves, but $G$. anthracina can immediately be recognized by its smaller petioles (4-7 vs $8-13 \mathrm{~mm}$ ), its acute instead of decurrent leaf base and by its smaller leaves ( $7-14$ by $2-4$ vs $14-22$ by $5-7 \mathrm{~cm}$ ). 


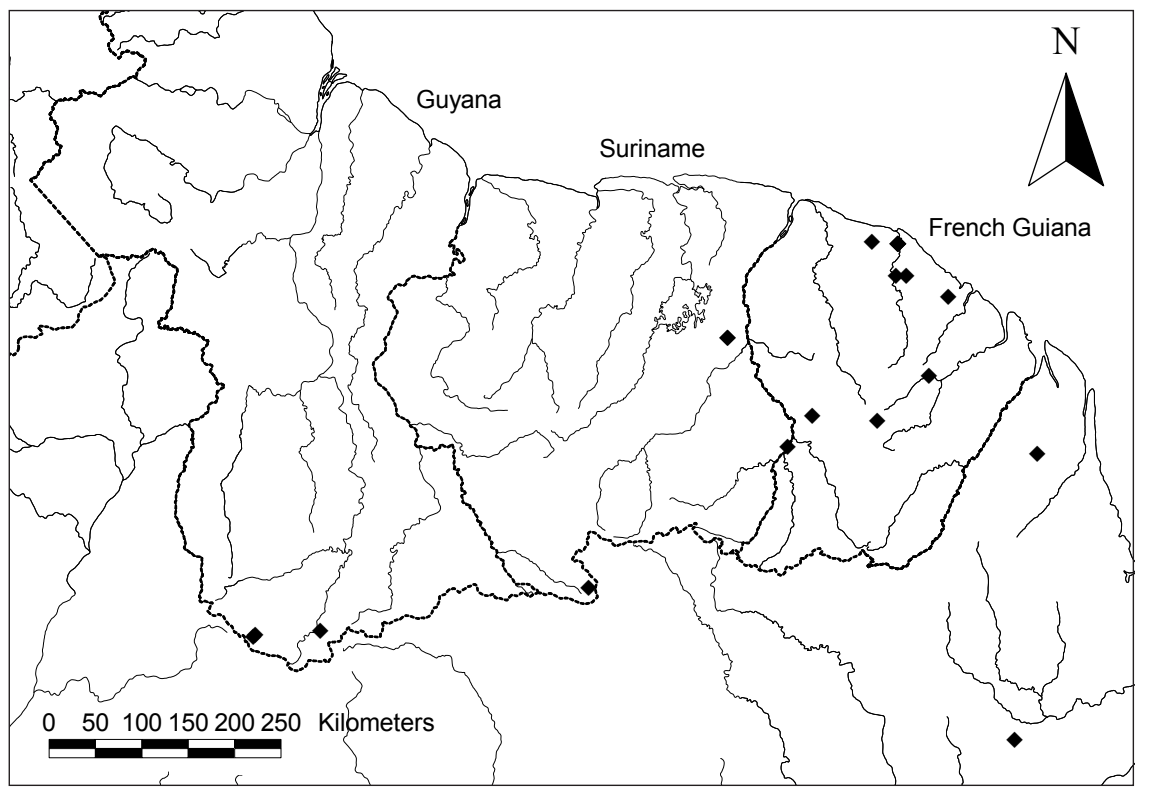

Map 1. Distribution of Guattria anthracina Scharf \& Maas in the Guianas.

4. The monocarps of collections from the Lely Mts (Suriname) are slightly deviating in being more elongated and more pointed.

5. Fleury 921 (CAY), Fleury 1104 (CAY), Molino \& Sabatier 1975 bis (U), Purwanto 983 (CAY) and Scharf 87 (CAY, LZ, U) from French Guiana, all nearly identical sterile collections, were recognized as juvenile forms of this species with very narrow leaves of $8-14$ by $1.5-2 \mathrm{~cm}$.

6. Mori et al. 15039 was the base for ' $G$. aff. oblonga' in Maas \& Maas-van de Kamer (2002). This collection is included here in G. anthracina. Guatteria oblonga R.E. Fr. is only known by the type-collection (Mélinon s.n.) from the Maroni R. in French Guiana, collected in 1862. Guatteria anthracina can be distinguished from G. oblonga by its narrower leaves (7-14(-16) by $2-4$ vs $10-16$ by $3-5 \mathrm{~cm})$, its longer petiole (4-7 vs 3-4 $\mathrm{mm}$ ) and by its petals, which are densely covered with short, straight, silvery hairs (vs long, curly and rusty brown hairs). Furthermore, petals in $G$. anthracina are obovate (vs elliptic), the fruiting receptacle is smaller (diameter $4-5$ vs $7 \mathrm{~mm}$ ) and the monocarps are more elongate (9-11 by $4-5$ vs 8 by $5 \mathrm{~mm}$ ). The loose flowers in the bag of Mélinon s.n. (P) fit perfectly with the remnants of the pedicels on the twigs.

Selection of other specimens (21 collections) examined:

BRAZIL: Amapá. Mun. Oiapoque, 35 km SSE of Oiapoque on BR 156, Daly et al. 3780 (U); Mun. Macapá, road from Cupixi to Rio Vila Nova, Rabelo et al. 3201 (U). - Amazonas. Reserva Florestal Ducke, Assunção 161 (U), 204 (U), Davidson \& Martinelli CD10008 (U), Dick 135 (U), Gottsberger 22-050891(U), Miralha, Maas \& Maas 282 (U), Oliveira et al. A1769(U), Ramos 1871 (U), Ribeiro \& Pereira 1601 (U), Webber 1472 (U); São Paulo de Olivença, Cid et al. 8556 (U). 
French Guiana: Saül, Monts la Fumée, 200-400 m, Mori et al. 15039 (MO, P, U); Crique Plomb, Prévost \& Sabatier 4622 (CAY, U); Piste de St. Elie, Sabatier \& Prévost 3580 (P, U), 3660 (B, NY, U, US), 3940 (B, G, NY, U); Basin of Maroni R., Grand Inini R., Sabatier \& Prévost 3350 (CAY, G, K, P, U); Cayenne, Patawa to Tonnégrande R., 26 m, Scharf 87 (CAY, LZ, U).

GuYANA: Takutu-U, Essequibo R., 4 km of Konashen Rapids and Mt Zibingatzako, 240-260 m, Clarke 3224 (NY, U, US); Wassarai Mts, 12 km S of Kassikaityu R., 500-750 m, Clarke et al. 8481 (U), idem, 915 m, Clarke et al. 8608 (U).

SuRINAME: Lely Mts 500-700 m, Mori \& Bolten 8544 (NY, U, US); Sipaliwini savannah, 310 m, Oldenburger et al. 1103 (U).

\section{Guatteria elegans Scharf, spec. nov. - Fig. 2; Map 2}

Foliis parvis venis secundariis paucis sub angulo valde acuto exeuntibus distincta. Typus: C. Feuillet et al. 10256 (holo NY; iso BRG, U), French Guiana, Régina, Mt Tor-

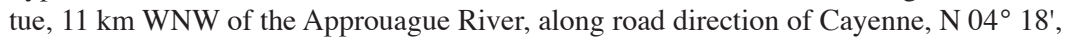
W $52^{\circ} 22^{\prime}, 200-450 \mathrm{~m}, 18$ June 1988.

Treelet, c. $4 \mathrm{~m}$ tall; young twigs sparsely to densely covered with appressed, short hairs, very soon glabrous. Leaves: petiole $3-5 \mathrm{~mm}$ long, $1 \mathrm{~mm}$ diam.; lamina very narrowly elliptic, $10-16$ by $3-4 \mathrm{~cm}$, chartaceous to semicoriaceous, base acute $\left(50-60^{\circ}\right)$, apex acuminate (acumen 15-25 mm long), satiny reddish dark brown and glabrous above, yellowish brown and glabrous below, primary vein glabrous above, sparsely covered with appressed, short, brownish to yellowish hairs below, secondary veins impressed
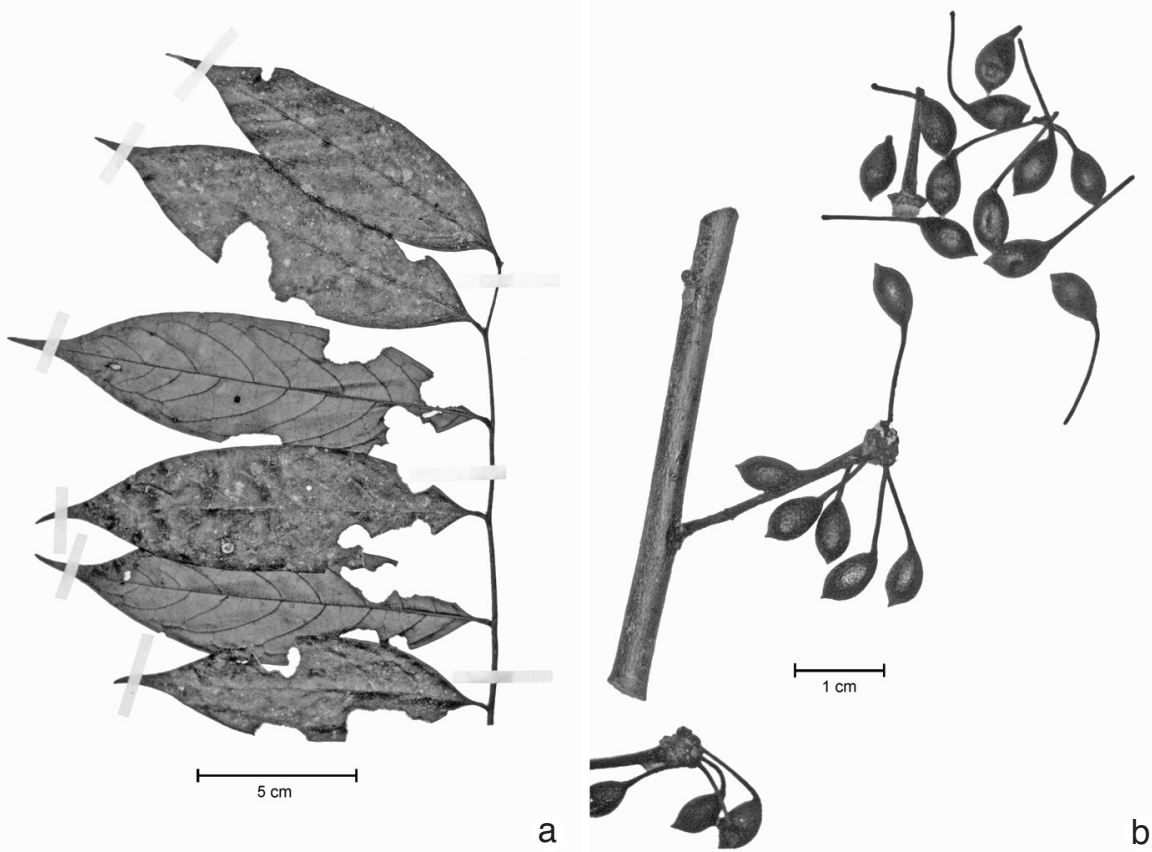

Fig. 2. Guatteria elegans Scharf. a. Leaved twig; b. fruits (a. Feuillet et al. 10256 (NY); b. Feuillet et al. $10256(\mathrm{U}))$. 
and sometimes rather indistinct above, very distinct below, 5-7(-8) on either side of primary vein, angle of secondary vein with primary vein $30-40^{\circ}$, indistinctly loop-forming at angles of c. $80^{\circ}$, smallest distance between loops and margin 2-3 mm. Flowers solitary; pedicels c. $20 \mathrm{~mm}$ (fruiting c. $25 \mathrm{~mm}$ ) long, sparsely covered with appressed, very short, brownish hairs, soon glabrous; sepals broadly triangular, c. 2 by $3 \mathrm{~mm}$, apically reflexed, glabrous on both sides; petals and stamens not seen; carpels 50-70, brown, some brown hairs in between. Monocarps 10-25, green in vivo, dull dark reddish brown in sicco, ellipsoid, c. 8 by $4-5 \mathrm{~mm}$, sparsely covered with appressed hairs, soon glabrous, some hairs remaining at the apex, apex apiculate (apiculum $<1 \mathrm{~mm}$ long), stipes 11-15 mm long, very slender, maturing red. Seeds satiny reddish brown, ellipsoid, $6-7$ by c. $4 \mathrm{~mm}$, slightly pitted in vertical rows.

Distribution - French Guiana, known from the type locality only.

Habitat \& Ecology - Low montane rainforest, on lateritic soil. At elevations of $200-450 \mathrm{~m}$.

Phenology - Flowering: May to June; fruiting: June.

Etymology - The species epitheton of 'G. elegans' refers to the slender and elegant appearance of its small leaves, which is caused by an extraordinary low number of secondary veins and an unusually sharp angle between primary vein and secondaries. The fruits are also quite small, and with very slender stipes.

Note - A sharp angle of $30-40^{\circ}$ between primary vein and secondaries is not occurring in any other Guatteria species in the Guianas and Brazilian Amazonia.

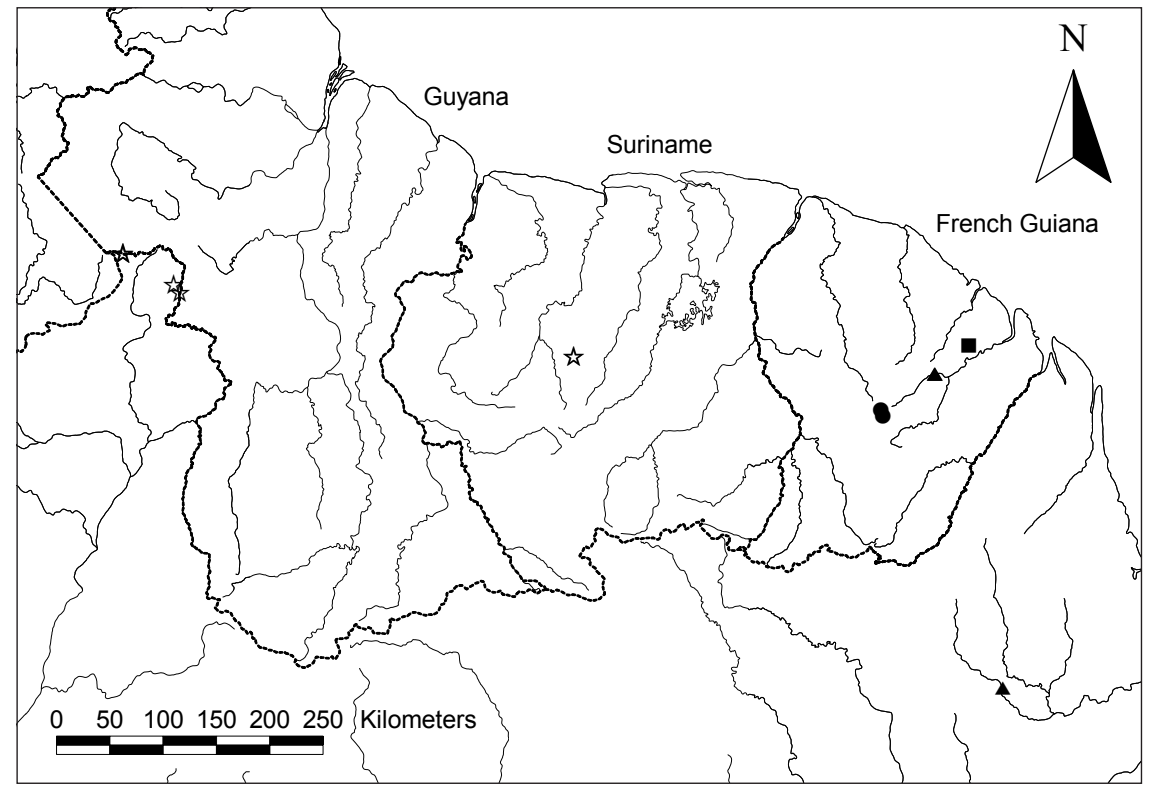

Map 2. Distribution of Guatteria elegans Scharf (অ), G. leucotricha Scharf \& Maas (•), G. minutiflora Scharf \& Maas (灾), and G. pannosa Scharf \& Maas ( $\mathbf{\Delta}$ ) in the Guianas. 
3. Guatteria leucotricha Scharf \& Maas, spec. nov. - Fig. 3; Map 2

Species foliis angustis basi attenuatis, marginibus revolutis, facie abaxiali pilis appressis albis vel argenteis dense obtectis distincta. - Typus: Mori \& Boom 15360 (holo NY; iso CAY, P, U, US), French Guiana, Saül, along road to airport, N $03^{\circ} 37^{\prime}$, W $53^{\circ} 12^{\prime}$, 200-400 m, 8 Dec. 1982.

= Guatteria spec. $A$, in Maas \& Maas-van de Kamer (2002: 62).

Tree 20-30 m tall, 35-45 cm diam., with steep, simple, round buttresses; young twigs densely covered with appressed, short hairs, very soon glabrous. Leaves: petiole 4-5 by $1-1.5 \mathrm{~mm}$; lamina narrowly elliptic to narrowly obovate, $9-14$ by $2-3 \mathrm{~cm}$, chartaceous to subcoriaceous, base attenuate, apex acuminate (acumen 10-15 mm long), margin recurved, dull and greyish green to brown above, brown below, densely covered with appressed, silvery, long hairs above, very soon glabrous, densely covered with appressed, silvery hairs below, secondary veins indistinct, slightly raised above, 8-13 on either side of primary vein, angle of secondary veins with primary vein $60-70^{\circ}$, indistinctly loop-forming. Flowers unknown, but following observations on fruiting specimens: solitary or in pairs on older leafless parts of whip-like branches; pedicels c. $10 \mathrm{~mm}$ long, sparsely covered with appressed, whitish hairs. Monocarps 5-20, maturing dark purple in vivo, shiny black in sicco, ellipsoid to obovoid, 7-9 by 5-7 $\mathrm{mm}$, apex rounded to minutely apiculate (apiculum $<0.5 \mathrm{~mm}$ long), sparsely covered with
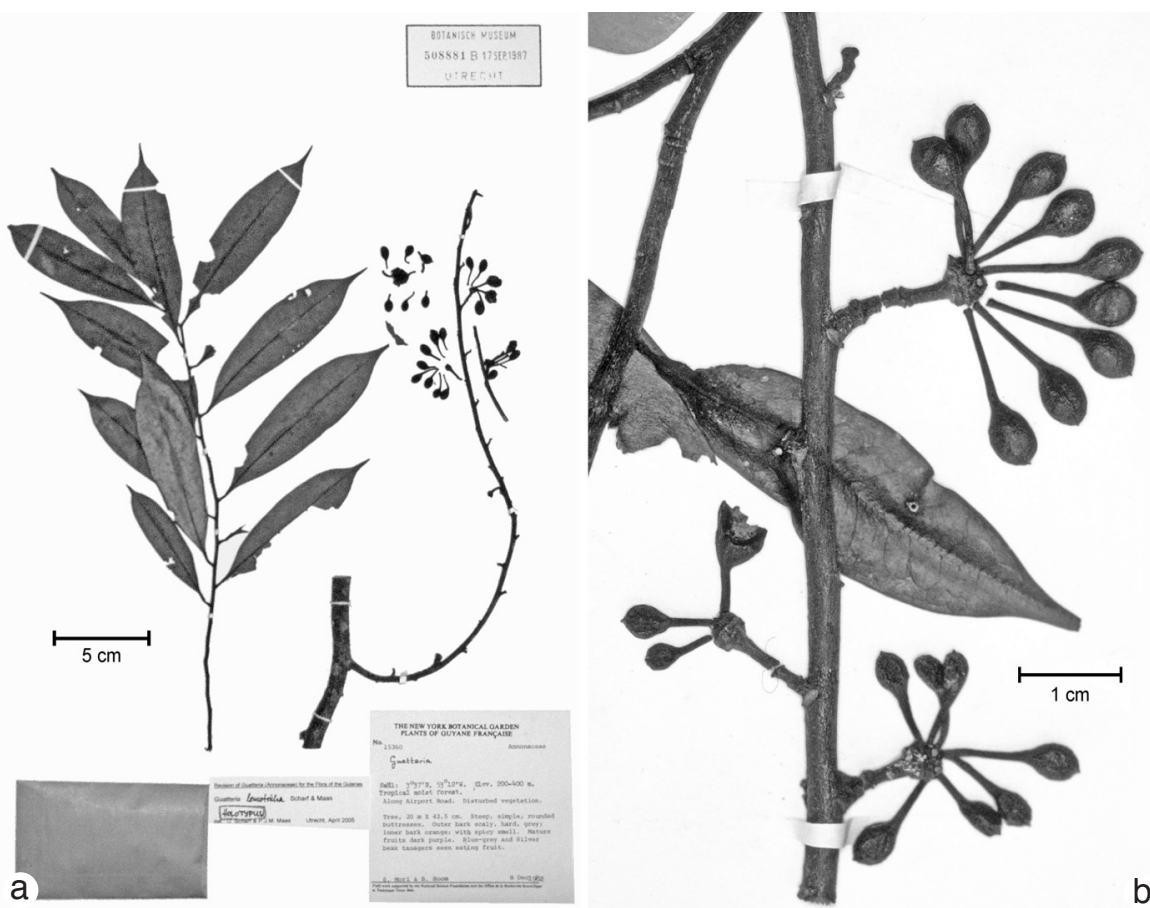

Fig. 3. Guatteria leucotricha Scharf \& Maas. a. Whip-like twig from the previous growing period, set with flowers and flowerless top of the twig; b. fruits (a. Mori \& Boom 15360 (U); Mori et al. $24197(\mathrm{U}))$. 
appressed, whitish hairs, glabrous when mature, stipes $10-13$ by c. $1 \mathrm{~mm}$, stout. Seeds shiny red-brown, c. 7 by $4 \mathrm{~mm}$, pitted.

Distribution - Endemic to French Guiana, the region of Saül.

Habitat \& Ecology - In moist forest, disturbed vegetation. Elevation 200-400 m.

Phenology - Fruiting: September and December.

Etymology - Guatteria leucotricha is named after its whitish or silvery long hairs at the lower side of the leaves.

Note - Guatteria leucotricha is highly typical by its narrow, long-attenuate leaves with recurved margins and by its indument of whitish or silvery hairs on the lower side of the lamina, a set of characters not met in any other Guianan species.

Paratype:

French Guiana: Saül, Route de Bélizon, between Eaux Claires and entrance to Grand Boeuf Mort Trail, Mori et al. 24197 (NY, U).

\section{Guatteria minutiflora Scharf \& Maas, spec. nov. - Fig. 4; Map 2}

Species floribus minutis et foliis brevibus (atratis in sicco) distincta. - Typus: Henkel et al. 1156 (holo U; iso BRG, US), Guyana, Potaro-Siparuni Region, Pakaraima Mts, Upper Ireng R., $2 \mathrm{~km} \mathrm{E}$ of Cipo settlement on $\mathrm{N}$ end of adjacent ridge, $750 \mathrm{~m}, \mathrm{~N} \mathrm{04^{ \circ }} 49^{\prime}$, W $60^{\circ} 01^{\prime}, 3$ Feb. 1993.

= Guatteria cf. trichostemon sensu Jansen-Jacobs (1976: 671); not R.E. Fr.

Tree, 4-15 m tall; young twigs sparsely to densely covered with erect, long, dark brown hairs, soon glabrous. Leaves: petiole $3-7$ by $1-1.5 \mathrm{~mm}$; lamina narrowly elliptic to ovate, $5-10$ by $2-3.5 \mathrm{~cm}$, chartaceous, base acute, apex acuminate (acumen 5-15 mm long), leaden greyish black to whitish brown above, blackish to dark brown below, glabrous above, except for some incurved, blackish brown hairs along the primary vein, sparsely covered with erect hairs below, secondary veins indistinct, raised above, 7-10 on either side of primary vein (intermingling with intersecondaries), angle of secondary veins with primary vein $65-75^{\circ}$, loop-forming at acute to right angles, smallest distance between loops and margin 2-3 mm. Flowers solitary, rarely 2 per axil; pedicels $7-12(-20) \mathrm{mm}$ long, densely covered with erect hairs; sepals triangular, $3-4$ by $2-3 \mathrm{~mm}$, apically reflexed, outer side densely covered with appressed, long, reddish brown hairs, inner side glabrous; petals ovate, c. 5 by $3 \mathrm{~mm}$ (probably immature), green in vivo (Henkel et al. 1156: black tipped in green), outer petals rather densely covered with appressed or curly, long hairs on both sides, inner petals on the outer side with a characteristic long-haired triangle in the centre, inner side glabrous or nearly so; stamens yellow in vivo and sicco, 90-110, c. $1 \mathrm{~mm}$ long, slightly umbonate, connective shield densely papillate; carpels 30-40, blackish, sparsely covered with very short, whitish hairs. Monocarps 10-30, green in vivo, black to dark reddish brown in sicco, ellipsoid, 9-12 by c. $5 \mathrm{~mm}$, apiculate (apiculum $<1 \mathrm{~mm}$ long), glabrous, stipes purple to red when ripe, 5-15 mm long, very slender. Seeds shiny, maroon, slightly grooved, ellipsoid to ovoid, c. 8 by $5 \mathrm{~mm}$.

Distribution - Central Suriname and Western Guyana.

Habitat \& Ecology - In high altitude forest, on mountain tops or on slopes, together with typical Guayana Shield highland vegetation, on moist places (seepage bog), on white sand or sandstone with peat and grey sandy clay. Elevation 750-1500 m. 

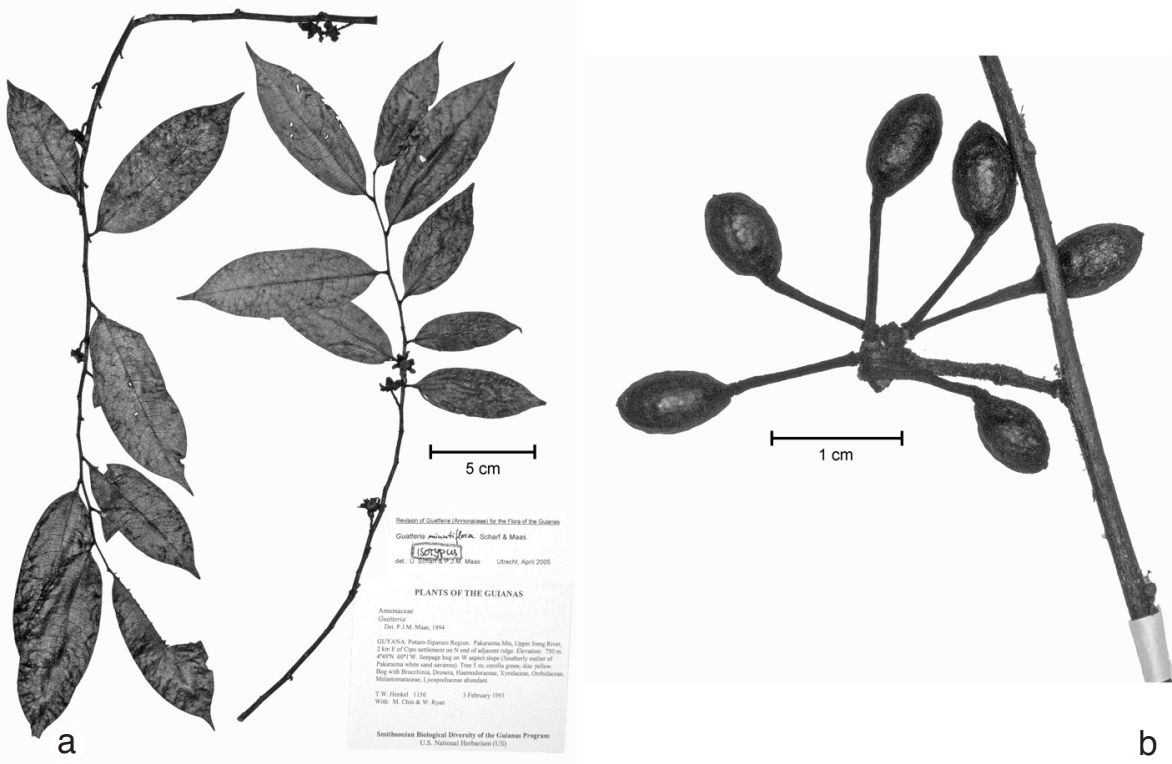

Fig. 4. Guatteria minutiflora Scharf \& Maas. a. leaved twig with flowers; b. fruits (a. Henkel 1157 (US); b. Clarke 11984 (U)).

Phenology - Flowering: January to February; fruiting: January to March.

Etymology - The specific epithet minutiflora was chosen regarding the small flowers present in the material available.

Notes - 1. Guatteria minutiflora is very easily distinguishable from all Guianan species by its small, often blackish drying leaves and by its minute flowers with petals of not more than 5 by $3 \mathrm{~mm}$.

2. The collections $B W 5654$ and $B W 5711$ were labelled $G$. cf. trichostemon R.E. Fr. G. trichostemon is a lowland species occurring further South in Western Amazonian Brazil, near São Paulo de Olivença. Morphologically, G. trichostemon is different by e.g. a glossy upper surface of the leaf, longer, very slender pedicels of 25-30 mm length, and a conspicuous bend in the middle of the pedicel which marks the articulation. The latter feature was not observed in any collection from the Guianas.

Paratypes:

GuYANA: Cuyuni-Mazaruni Region, Mt Maringma, 1400 m, Clarke et al. 11542 (U), idem, 1490 m, Clarke et al. 11916 (U), idem, 1360 m, Clarke et al. 11984 (U); Potaro-Siparuni Region, Pakaraima Mts, Cipo Mt, 2-4 km from headwaters of Cipo Cr., 1250 m, Henkel et al. 1056 (NY, U, US).

SURINAME: Hendriktop, 1080 m, BW (Boschwezen Suriname) 5654 (U), BW 5711 (S, U).

\section{Guatteria pannosa Scharf \& Maas, spec. nov. - Fig. 5; Map 2}

Species alabastris acutis, ramulis novellis, floribus et monocarpis indumento pannoso vestitis differt. - Typus: Barrier \& Feuillet 2633 (holo CAY), French Guiana, Approuague R., Arataye R., Sauts Pararé, N 4 02', W 52 42', 12 Feb. 1981. 

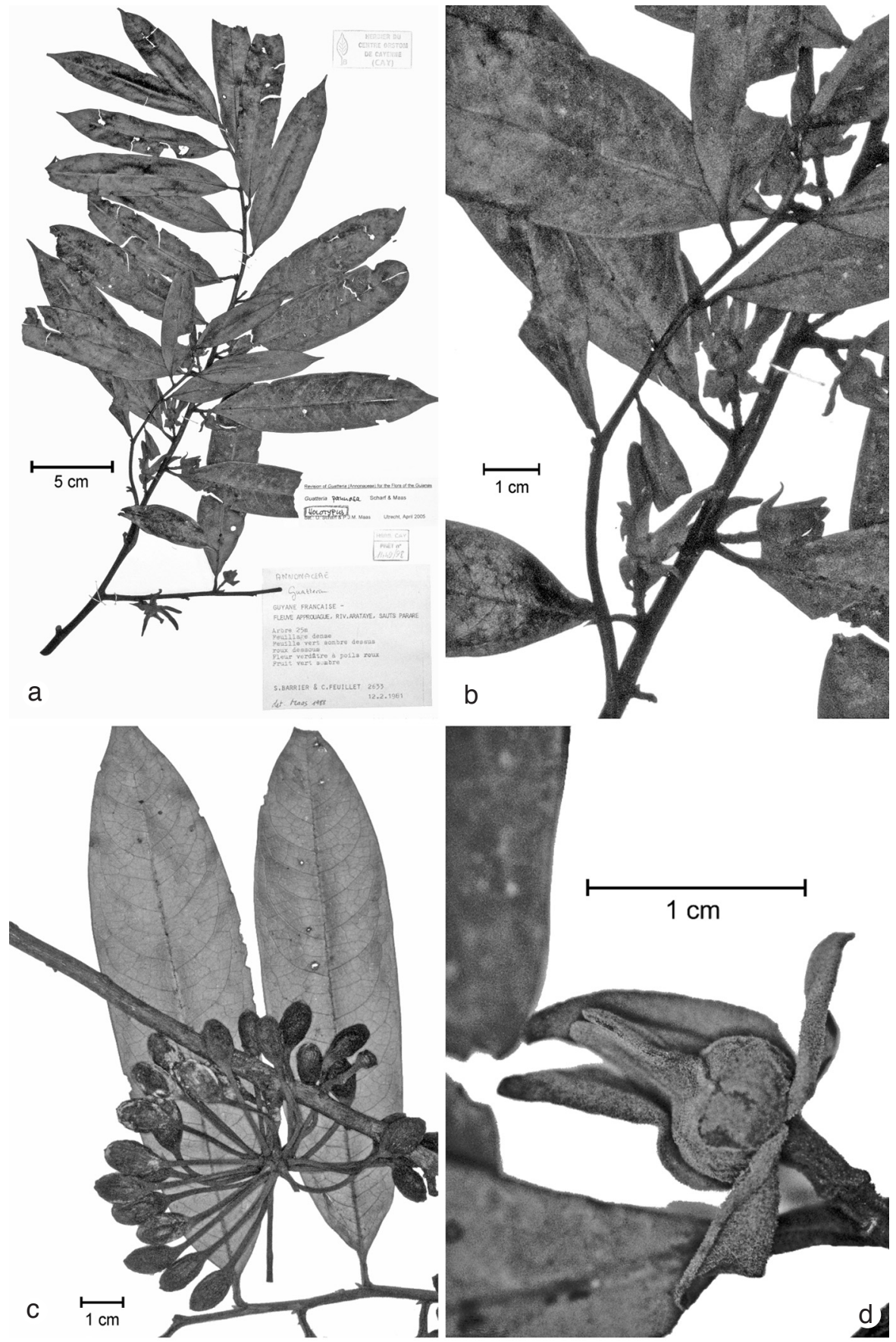

Fig. 5. Guatteria pannosa Scharf \& Maas. a. Leaved twig with flowers and flower buds; b. insertion of flower buds along the twig; c. fruits and leaves; d. pointed petals at the flower bud (a, b, d. Barrier \& Feuillet 2633 (CAY); c. Barrier 3865 (CAY)). 
Tree, 4-25 m tall; young twigs densely covered with erect, curly, brown hairs, persistent one growing period or even longer. Leaves: petiole $6-8$ by $1-2 \mathrm{~mm}$, distinctly canaliculate above; lamina narrowly oblong-elliptic, rarely elliptic, $10-20$ by $2.5-4 \mathrm{~cm}$, coriaceous, base acute, apex shortly acuminate (acumen 5-10 mm long), greyish green (in vivo dark green) above, pale brown (in vivo reddish) below, glabrous above, but primary vein with some wavy hairs, densely covered with appressed, brown hairs below, secondary veins distinct, prominent above, $10-15$ on either side of primary vein, angle of secondary veins with primary vein c. $70^{\circ}$, loop-forming at right to obtuse angles, smallest distance between loops and margin 2-3 mm. Flowers solitary or in pairs; flower buds distinctly pointed, pedicels $8-10$ by $1 \mathrm{~mm}$, to 15 by $3 \mathrm{~mm}$ in fruit, densely covered with a felt-like indument of curly, brown hairs (in fruit sparsely so to glabrous), almost woody; sepals triangular, $8-10$ by $5-6 \mathrm{~mm}$, both sides densely covered with a felt-like indument of curly, reddish brown hairs; petals narrowly triangular, 20-25 by 6-8 mm, both sides densely covered with curly, reddish brown hairs, margins reflexed; stamens pale yellow in sicco, 200-250, c. $1.2 \mathrm{~mm}$ long, connective shield impressed, densely papillate; carpels arranged in a trigonal pyramid-like structure, c. 60, dark brown, sparsely covered with whitish, short hairs. Monocarps 25-30, maturing blackish green in vivo, dark to rusty brown in sicco, narrowly ellipsoid, $10-14$ by $6-7 \mathrm{~mm}$, apex minutely apiculate (apiculum $<0.3 \mathrm{~mm}$ long), young monocarps densely, older ones sparsely covered with curly, brown hairs, stipes $20-25$ by $1 \mathrm{~mm}$, densely covered with curly, short, brown hairs. Seeds c. 12 by $5 \mathrm{~mm}$, smooth, shiny, red-brown.

Distribution - French Guiana and adjacent Brazil (Amapá).

Habitat and Ecology - In upland.

Phenology - Flowering: February; fruiting: August to October.

Vernacular names - French Guiana: Baka pao (Saramaka, Boni), Pandiecou.

Etymology - Guatteria pannosa has been so named because of its dense felt-like (pannose) indument of appressed to curly, reddish brown hairs on all parts except the upper surface of the leaf.

Notes - 1. Guatteria pannosa is a very distinct species by its narrow and coriaceous leaves, pointed flower buds, narrow petals, and its felt-like indument. The monocarps are distinctively narrowly ellipsoid. To complete the description, two collections from adjacent Brazil, which doubtless belong to G. pannosa, are included.

2. Guatteria pannosa has a number of features in common with an as yet undescribed Panamanian species: coriaceous leaves, pointed flower buds, flowers' and fruits' general appearance, indument of erect and curly, brown hairs on the young twigs. Guatteria pannosa differs from the Panamanian species by its narrowly oblong-elliptic leaves (10-20 by $2.5-4 \mathrm{~cm}$, vs narrowly elliptic to narrowly ovate, $20-23$ by $7-8 \mathrm{~cm}$ ), the indument on the lower side of the leaf (densely covered with long, appressed hairs vs sparsely covered with very short, appressed hairs or glabrous), and by its longer fruiting stipes (20-25 vs 9-14 mm). The Panamanian material (cf. list of specimens below) will be described soon, and further discussion will be given then (R.H.J. Erkens et al., in this volume).

Paratypes:

FRENCH GUIANA: Approuague R., Rivière Arataye, Sauts Pararé, Barrier 3865 (CAY, U), idem, Villiers \& Feuillet 1790 (U, US).

BRAZIL: Amapá. Rio Araguari, at mouth of Anicahy, camp 14, Pires et al. 51575 (NY, U), 51239 $(\mathrm{NY})$. 
Specimens examined for Guatteria spec. nov. Panama:

PANAmA: Colón: Santa Rita Ridge, Aizprúa \& Arauz B3375 (U); Aranda \& Galdames 3022 (U); Luque et al. 509 (U); Maas et al. 9564 (U); 9570 (U); La Llana, Chagres National Park, Luque et al. 566 (U); road to Sierra Llorona, Galdames 4473 (U); Comarca de San Blas, Cangandi, De Nevers \& Herrera $7168(\mathrm{U})$.

\section{ACKNOWLEDGEMENTS}

The work resulting in this publication was carried out in the context of the Flora of the Guianas project, a critical treatment of the plant taxa occurring in the Guianas and being a contribution to Flora Neotropica in a close cooperation between the Universität Leipzig, Germany, Herbarium LZ and the Nationaal Herbarium Nederland, Utrecht branch (U). Latin diagnoses were corrected by Lubbert Y.Th. Westra. Roy H.J. Erkens helped a lot generating the distribution maps using ESRI data (NYBG, 2003). The photos were made by the first author from herbarium sheets on loan in U and LZ. The research was only possible by loans and duplicates sent from AAU, B, BBS, BM, BR, BRG, C, CAY, F, FDG, K, MO, NY, P, S and US. All colleagues involved are gratefully acknowledged.

\section{REFERENCES}

Boggan, J., V. Funk, C. Kelloff, M. Hoff, G. Cremers \& C. Feuillet. 1997. Checklist of the plants of the Guianas (Guyana, Surinam, French Guiana). 2nd edition. Biological Diversity of the Guianas Program, National Museum of Natural History, Smithsonian Institution, publication number 30, Washington.

Chatrou, L.W. 1998. Changing genera. Systematic studies in Neotropical and West African Annonaceae. PhD Thesis. Utrecht University.

Chatrou, L.W., H. Rainer \& P.J.M. Maas. 2004. Annonaceae. In: N. Smith, S.A. Mori, A. Henderson, D.W. Stevensen, S.V. Heald (eds.), Flowering plants of the Neotropics: 18-20. Princeton, New Jersey, USA.

Fries, R.E. 1939. Revision der Arten einiger Annonaceen-Gattungen. V. Acta Horti Berg. 12: 289577.

Fries, R.E. 1941. Neue amerikanische Annonaceen. Acta Horti Berg. 13: 103-116.

Fries, R.E. 1943. Einige Gesichtspunkte zur systematischen Gruppierung der amerikanischen Annonaceen-Gattungen. Ark. Bot. 30A (8): 1-31.

Fries, R.E. 1948a. Contributions to the flora of tropical America XLVII. Annonaceae new to British Guiana. Kew Bull. 1948: 229-235.

Fries, R.E. 1948b. New or noteworthy Annonaceae from tropical America. Kungl. Svenska Vetenskapsakad. Handl., ser. 3, 24 (10): 3-12.

Fries, R.E. 1948c. Annonaceae. In: B. Maguire et al., Plant explorations in Guiana in 1944, chiefly to the Tafelberg and the Kaieteur Plateau VI. Bull. Torrey Bot. Club 75: 640-642.

Fries, R.E. 1949. Sobre la caulifloría en la familia de las Anonáceas. Lilloa 16: 251-261.

Fries, R.E. 1950a. Contributions to the knowledge of the Annonaceae in northern South America. Ark. Bot. n.s. 1: 329-347.

Fries, R.E. 1950b. Three new species of Annonaceae from northern South America. Ark. Bot. n.s. 1: $445-451$.

Fries, R.E. 1952. Annonaceae. In: R. S. Cowan et al., Plant explorations of G. Wilson-Browne, S.J., in British Guiana. I. Kanuku Mountains. Brittonia 7, 5: 395-396.

Fries, R.E. 1953. Contributions to the flora of tropical America LIV. New trees and shrubs from British Guiana. Kew Bull. 1952: 255-257.

Fries, R.E. 1957a. Annonaceae. In: R.S. Cowan et al., New species and new records of plants in Guiana. Brittonia 8: 236f.

Fries, R.E. 1957b. Annonaceae. In: B. Maguire, J.J. Wurdack et al., The botany of the Guayana Highland. Part II. Mem. New York Bot. Gard. 9: 325-331.

Fries, R.E. 1960. Annonaceae. In: B. Maguire, J.J. Wurdack et al., The botany of the Guayana Highland. Part IV. Mem. New York Bot. Gard. 10: 22f. 
Hoff, M. \& G. Cremers. 1996. Index des noms de lieux des récoltes botaniques en Guyane française. Studies on the Flora of the Guianas no 77. Herbier du Centre ORSTOM de Cayenne, France.

Hollowell, T., P. Berry, V. Funk \& C. Kelloff. 2001. Preliminary checklist of the plants of the Guiana shield. Volume 1: Acanthaceae - Lythraceae. Biological Diversity of the Guianas Program, National Museum of Natural History, Smithsonian Institution, publication number 57, Washington.

Jansen-Jacobs, M. 1976. Annonaceae. In: A. A. Pulle. Flora of Suriname. Additions and corrections to Vol. II, Part 1-2. 1976: 658-687. Foundation van Eedenfonds, Leiden.

Johnson, D.M. \& N.A. Murray. 1990. New species of Guatteria (Annonaceae) from the Guayana Highland. Ann. Missouri Bot. Gard. 77, 3: 598-600.

Maas, P.J.M. \& H. Maas-van de Kamer. 2002. Annonaceae (Custard-apple Family). In: S.A. Mori, G. Cremers, C.A. Gracie, J.-J. de Granville, S. V. Heald, M. Hoff \& J.D. Mitchell (eds.), Guide to the vascular plants of Central French Guiana. Part 2. Dicotyledons. Mem. New York Bot. Gard. 76: 53-67. The New York Botanical Garden Press, New York.

Ribeiro, J.E.L.S., P.J.M. Maas, H. Maas \& J.M. Miralha. 1999. Annonaceae. In: J.E.L.S. Ribeiro et al., Flora da Reserva Ducke: 121-135. INPA, Manaus.

Scharf, U., P.J.M. Maas \& W. Morawetz. 2005. Five new species of Guatteria (Annonaceae) from the Pakaraima Mountains, Guyana. Blumea 50: 563-573.

Scharf, U., P. J.M. Maas \& W. Morawetz. In prep. Guatteria richardii (Annonaceae) rediscovered and two related new species from French Guiana.

Steyermark, J., P.J.M. Maas, P.E. Berry, D.M. Johnson, N.A. Murray \& H. Rainer. 1995. Annonaceae. In: P.E. Berry, B.K. Holst \& K. Yatskievych (eds.), Flora of the Venezuelan Guayana. Vol. 2: 413-469. Missouri Botanical Garden, St. Louis.

The Lands and Surveys Department. 2001. Gazetteer of Guyana. Published for the Government of Guyana by the Lands and Surveys Department and the German Agency for Technical Cooperation (GTZ). Georgetown.

The New York Botanical Garden. 2003. A digital basemap of the Americas for mapping and analyzing plant distributions. CD-ROM.

MAPS:

An international travel map of Surinam. Nr. 705. Scale 1 : 750,000. International travel maps, ITMB Publishing, Vancouver, Canada, 1998.

An international travel map of Guyana. Nr. 748. Scale $1: 850,000$. International travel maps, ITMB Publishing, Vancouver, Canada, 1998.

Guyane. Carte touristique au 1 : 500,000. No. 3615. Institut Géographique National Paris, 1995.

\section{INTERNET:}

Geonames Query Home Page. http://gnswww.nga.mil/geonames/GNS/index.jsp

Falling Rain Genomics, Inc., World Index. http://www.fallingrain.com/world/

\section{IDENTIFICATION LIST}

The abbreviations behind the collector numbers refer to the following taxa:

$\begin{aligned} & \text { Guatteria ant }=\text { anthracina } \\ & \text { ele }=\text { elegans } \\ & \text { leu }=\text { leucotricha } \\ & \text { min }=\text { minutiflora } \\ & \text { pan }=\text { pannosa } \\ & \text { snP }=\text { spec. nov. Panama }\end{aligned}$

Aizprúa \& Arauz B3375: snP - Aranda 3022: snP - Assunçāo 161: ant; 204: ant. Barrier et al. 2633: pan; 3865: pan - BW (Boschwezen Suriname) 5654: min, 5711: min.

Cid et al. 8556: ant - Clarke 3224: ant - Clarke et al. 8481: ant; 8608: ant; 11542: min; 11916 : min; 11984: $\min$. 
Daly et al. 3780: ant - Davidson \& Martinelli CD10008: ant - De Nevers \& Herrera 7168: snP - Dick 135: ant.

Feuillet et al. 10256: ele - Fleury 921: ant; 1104: ant.

Galdames 4473: snP - Gottsberger 22-050891: ant.

Henkel 1056: $\min -$ Henkel et al. 1156: min.

Lindeman, Stoffers et al. 429: ant - Loubry 1705: ant.

Miralha, Maas \& Maas 282: ant - Molino \& Sabatier 1975bis: ant - Molino et al. 1053: ant - Mori \& Bolten 8544: ant - Mori \& Boom 15360: leu - Mori et al. 15039: ant; 24197: leu.

Oldenburger et al. 1103: ant - Oliveira et al. A1769: ant.

Pires et al. 51239: pan; 51575: pan — Prévost \& Sabatier 4622: ant - Purwanto 983: ant.

Rabelo et al. 3201: ant - Ramos 1871: ant - Ribeiro \& Pereira 1601: ant.

Sabatier et al. 2791: ant - Sabatier \& Prévost 3350: ant; 3580: ant; 3660: ant; 3940: ant — Scharf 87: ant.

Villiers et al. 1790: pan.

Webber 1472: ant. 